\title{
Water quality, seasonality, and trajectory of an aquaculture-wastewater plume in the Red Sea
}

\author{
Aya Hozumi ${ }^{1, *}$, Pei-Ying Hong ${ }^{2}$, Stein Kaartvedt ${ }^{3}$, Anders Røstad ${ }^{1}$, Burton H. Jones ${ }^{1}$ \\ ${ }^{1}$ King Abdullah University of Science and Technology (KAUST), Red Sea Research Center (RSRC), \\ Biological and Environmental Sciences \& Engineering Division (BESE), Thuwal 23955, Saudi Arabia \\ ${ }^{2}$ King Abdullah University of Science and Technology (KAUST), Water Desalination and Reuse Center, \\ Biological and Environmental Sciences \& Engineering Division (BESE), Thuwal 23955, Saudi Arabia \\ ${ }^{3}$ Department of Biosciences, University of Oslo, 0316 Oslo, Norway
}

\begin{abstract}
As aquaculture activity increases globally, understanding water mass characteristics of the aquaculture-wastewater plume, its nutrients, and its organic matter load and spatial distribution in the coastal recipient, is critical to develop a more sustainable aquaculture operation and to improve coastal management. We examined wastewater (estimated $42-48 \mathrm{~m}^{3} \mathrm{~s}^{-1}$ ) discharged from the largest aquaculture facility in the Red Sea and surveyed the area around the aquaculture outfall to characterize the biogeochemical properties of the wastewater plume and its spatial distribution. In addition, we assessed its associated microbial community structure. The plume was characterized by elevated levels of salinity, density, and turbidity, and traveled along paths determined by the bathymetry to form a dense, 1-3 m thick layer above the seafloor. The effluent was observed at least $3.8 \mathrm{~km}$ from the outfall throughout the year, but up to $8 \mathrm{~km}$ in early autumn. The total nitrogen concentration in the plume was more than 4 times higher than in surface waters $1.4 \mathrm{~km}$ from the outfall. High-throughput sequencing data revealed that bacterial and cyanobacterial communities significantly differed, and flow cytometry results showed that total cell counts were significantly higher at the outfall. Arcobacter, a genus associated with opportunistic pathogenic species (e.g. A. butzleri), was more abundant, while Prochlorococcus sp. was significantly less abundant at the outfall. This dense, bottom-flowing plume may have a detrimental impact on benthic and demersal communities.
\end{abstract}

KEY WORDS: Anthropogenic effluent · Microbial biomarkers · Nutrification · Coastal management

\section{INTRODUCTION}

Food security concerns and economic development are driving a worldwide increase in aquaculture. The largest aquaculture facility in the Red Sea is located in Al-Lith $\left(20.15^{\circ} \mathrm{N}, 40.25^{\circ} \mathrm{E}\right)$, spanning over $40 \mathrm{~km}$ of coastline and occupying 4000 ha of land for pond farms and hatcheries. The facility is important for the economy of the Kingdom of Saudi Arabia and for meeting the market demand for seafood. In 2014, this facility produced $13000 \mathrm{t}$ of prawn, accounting for $70-80 \%$ of its total biomass production; other products include sea cucumber, algae, and beta-carotene

${ }^{*}$ Corresponding author: aya.hozumi@kaust.edu.sa (produced in hypersaline ponds cultivating Dunaliella spp.) (N. Ayaril, M. Villarreal, National Aquaculture Group, pers. comm.). While the facility is a source of food and economic prosperity to the country, it is also a point source of anthropogenic wastewater to coastal waters of Al-Lith.

The potential conflict between coastal development and ecological conservation is a global issue, but tropical and subtropical regions are particularly at risk because their ecology often includes sensitive coral reefs and their associated communities, which are already threatened by global warming and ocean acidification (Carpenter et al. 2008). The receiving

() The authors 2018. Open Access under Creative Commons by Attribution Licence. Use, distribution and reproduction are unrestricted. Authors and original publication must be credited. 
waters surrounding Al-Lith host coral reef-associated fauna and are well known for an annual whale shark aggregation (Berumen et al. 2014). The potential conflict between coastal development and conservation (Islam \& Tanaka 2004) is therefore very pertinent.

Untreated aquaculture wastewater can contain high concentrations of nutrients (e.g. nitrogen, phosphorus), organic matter, suspended particulate matter (SPM), chemical substances (e.g. disinfectants, therapeutic chemicals), pathogens, and non-native organisms (Ackefors \& Enell 1994, Páez-Osuna 2001, Burford et al. 2003, Jackson et al. 2004). Concentrations of these contaminants could be high in Al-Lith's aquaculture wastewater since the pond farms are enriched with molasses, wheat bran, diammonium phosphate, and urea to create a zooplankton bloom before stocking ( $\mathrm{N}$. Ayaril \& M. Villarreal pers. comm.). Additionally, as there are no strong tidal currents in Al-Lith that mix and disperse the wastewater plume, organic matter from the discharge may settle at high concentrations into benthic pockets and form anoxic sediments that could alter bacterial populations. This could influence the processes catalyzed by bacteria and change the biogeochemical properties of the environment. Thus, aquaculture discharge is potentially a major anthropogenic nutrient input into the oligotrophic Red Sea. A previous study in Al-Lith revealed enhanced levels of lesioned Fungiidae corals, although with no significant relation to the distance from the outfall (Furby et al. 2014). Sawall et al. (2014) found that 'polluted' reefs near this outfall in Al-Lith have less coral cover, a shift in community composition toward bigger and stress-tolerant species, and a greater fraction of non-living substrate than its corresponding offshore reefs. They attributed the aquaculture discharge as the pollution source but had no data that characterized the pollution. Further assessment of more ecologically sensitive biomarkers, such as bacterial populations, that would be indicative of the water quality (e.g. presence of opportunistic pathogens, fecal indicators) is required.

Physical, chemical, optical, and biological characteristics of other anthropogenic discharges have been measured to describe water quality and to map their distribution. For instance, tracers such as temperature-salinity and the beam attenuation coefficient (660 nm) were used to describe and model the spatial distribution of a wastewater discharge in Sand Island, Hawaii, USA (Petrenko et al. 1998). Chemical and microbial assessment further found higher concentrations of ammonium, phosphate, and silicate, more particles larger than $70 \mu \mathrm{m}$, and higher concentrations of heterotrophic bacteria and Pro- chlorococcus in this plume layer than in the surrounding coastal water (Petrenko et al. 1997). Effluents with elevated levels of colored dissolved organic matter (CDOM) offshore San Diego, California, USA, were effectively characterized and tracked by an autonomous underwater vehicle (AUV) equipped with an optical CDOM sensor (Rogowski et al. 2012). No studies of this extent have been done in Al-Lith to reveal the characteristics and spatial distribution of the aquaculture facility's discharge.

In this study, we characterized and tracked the untreated discharge from the aquaculture facility using microbial communities as sensitive biomarkers. The objectives were (1) to identify the plume's physical, optical, chemical, and microbial water properties and seasonality, and (2) to map its trajectory in the coastal region.

\section{MATERIALS AND METHODS}

\section{Study site}

The study site at Al-Lith is located on the eastern coast of the south-central Red Sea (Fig. 1). The presence of whale sharks and manta rays in the region has recently received much attention (Berumen et al. 2014, Braun et al. 2014), with whale sharks aggregating from mid-February to May around Shi'b Habil, a submerged nearshore reef just $4 \mathrm{~km}$ from the aquaculture discharge (Fig. 1) (Berumen et al. 2014). Dugongs, mangrove patches, seagrass beds, coral reefs, and reef-associated fauna are also common in this region. Al-Lith's complex and steep coral reef structures are dispersed across the shallow (2-40 m) sandy bottom and seagrass beds.

The intake from the Red Sea to the facility has an estimated flow of $42-48 \mathrm{~m}^{3} \mathrm{~s}^{-1}$ (N. Ayaril pers. comm.). The wastewater from the ponds merges to form one main effluent plume. The discharge rates should be similar to seawater intake rates, although they will be modified by environmental factors such as evaporation and by aquaculture operations (e.g. water retained for hatcheries and beta-carotene farms). Apart from the wastewater passing through a settling basin, with an unknown retention time to reduce the suspended particle load, there is no additional treatment.

No other comparable anthropogenic discharge is known in the area. Municipal wastewater from Al-Lith's population of 130000 (2010 estimate; Knoema 2016) would only create a small fraction of this flow (Furby et al. 2014), and terrestrial runoff is minimal due to low precipitation rates. Construction of the aquacul- 


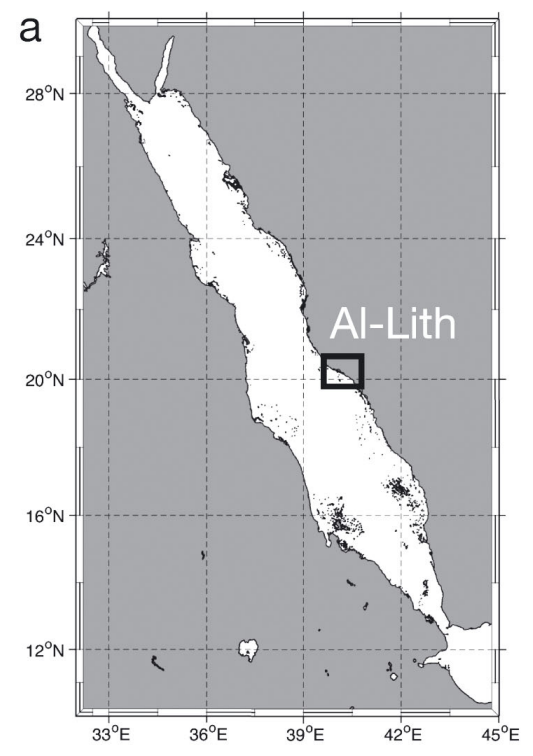

b

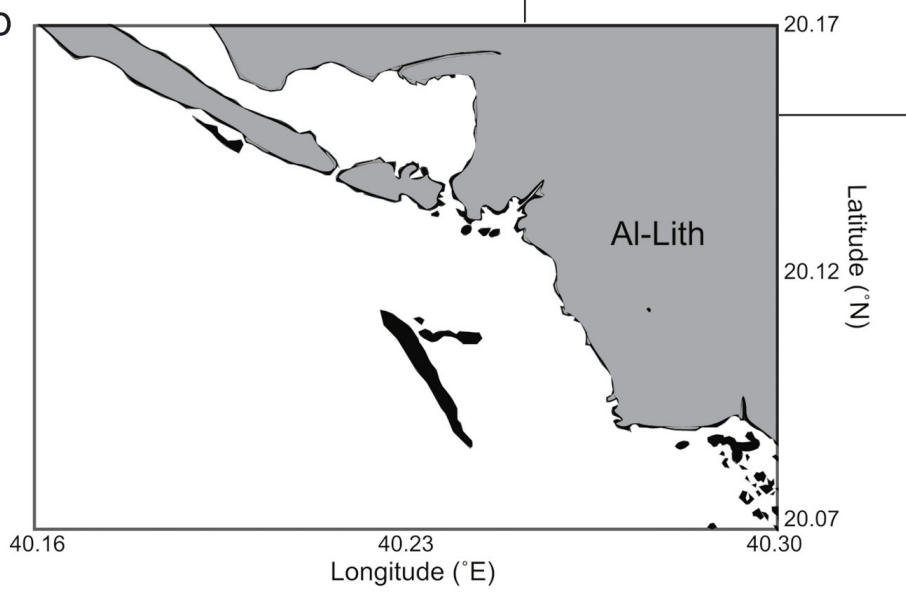

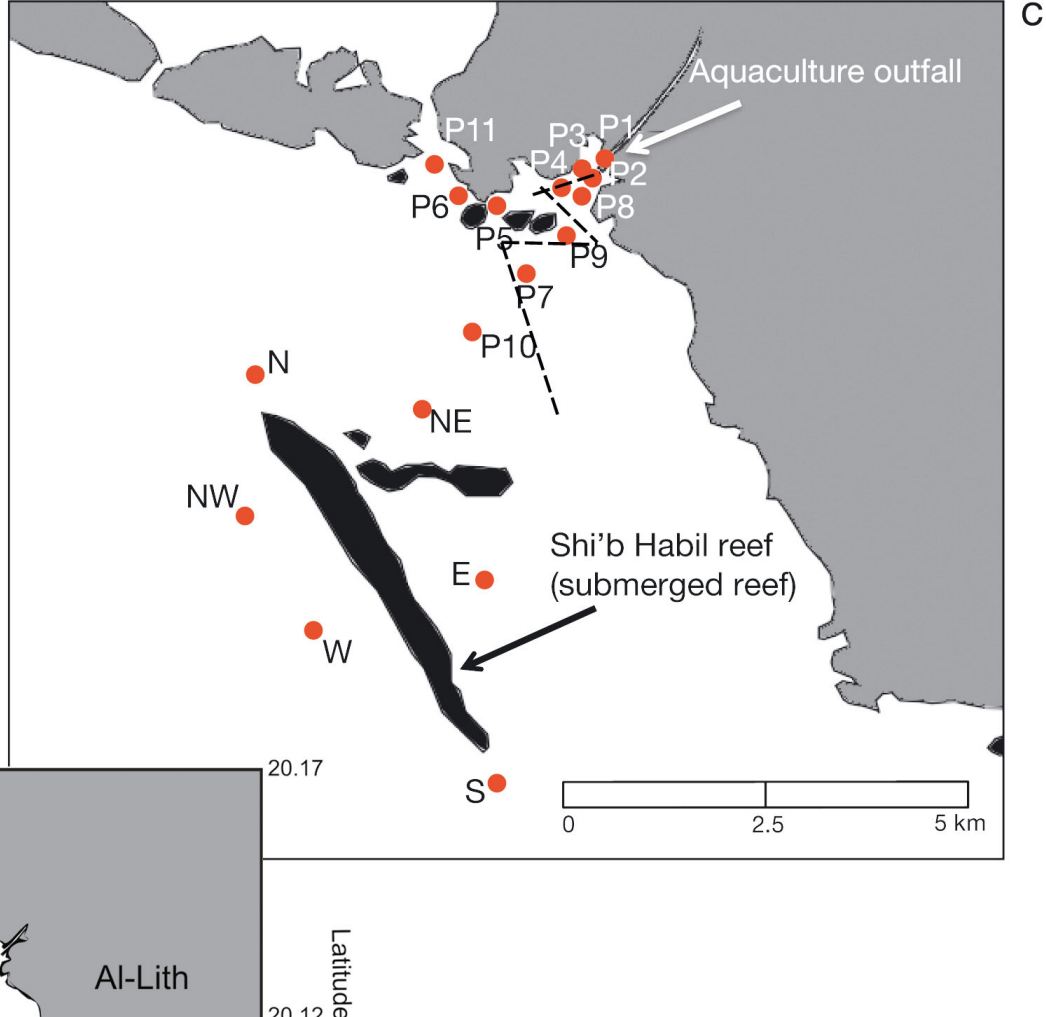

Fig. 1. (a) Red Sea, with additional maps showing (b) the coast of Al-Lith and (c) the outfall of the coastal aquaculture facility. The black features show Shi'b Habil, a submerged reef. The autonomous underwater vehicle (REMUS 100) survey line (dashed line) and monthly survey stations (red dots) are labeled. Stn E serves as the control station with ambient water conditions ture facility, since its establishment in 1986, replaced coastal mangrove patches (Gladstone et al. 1999), removing natural sinks for potential contaminants.

\section{Spatial surveys}

Two initial spatial surveys were made to map the path of the plume. First, an AUV (REMUS 100) surveyed the area offshore from the outfall on 4 December 2013. The AUV, traveling at 4 knots, followed a predetermined $5.5 \mathrm{~km}$ zigzag line at $1 \mathrm{~m}$ depth (Fig. 1), measuring temperature, salinity, chlorophyll a (chl a) fluorescence, and turbidity.

The second survey (15 January 2014) mapped the plume acoustically using a small boat with a portable $200 \mathrm{kHz}$ echosounder (SIMRAD EK 60) and GPS system. The acoustic measurements were complemented with repeated conductivity-temperature casts (Microcat 37SM, Seabird) along the survey track. The
GPS data were merged with the echosounder data in post-processing. A small part of the data was unusable due to failure of the GPS near the end of the echosounder survey. The path of the survey was chosen based on the real-time acoustic backscatter data, with the assumption that high acoustic backscatter from the turbid plume layer would enable spatial tracking of the plume in 3 dimensions. In practice, following the effluent proved difficult, due to the complex topography and lack of accurate, high-resolution bathymetric charts. This resulted in a complicated survey line, having to go back and forth in order to find and follow the plume signal.

\section{Monthly surveys}

Subsequent to the initial spatial surveys, monthly surveys were conducted from January 2014 to January 2015 (except October, due to logistical reasons). 
Vertical profiles were obtained to characterize the plume and assess its spatial distribution and seasonal variability. Profiles were taken at 17 stations in total. Seven were around the outfall, at varying proximities and directions (P1-P7), and 6 were located around Shi'b Habil submerged reef (N, NE, E, S, W, and NW; Fig. 1). Four additional stations (P8-P11), near the outfall, were added in July 2014 as part of a complementary field effort (Fig. 1). Because of the rapidly steep bathymetry and the boat's inability to maintain position in the intense discharge flow, the exact sampling location at the outfall (Stn P1) varied.

The profiling package used for monthly surveys included a CTD (Microcat 37SM, Seabird, or Ocean Seven 304, Idronaut), a 2-channel fluorometer and turbidity meter (FLNTUB, WETLABS), and a laser diffractometer (laser in situ scattering and transmissometry; LISST-100X Type-B, Sequoia Scientific). Dark counts for FLNTUB and LISST were taken with clean filtered Milli- ${ }^{\circledR}$ water prior to each deployment following manufacturer recommended procedures. During the LISST data-processing, the first 2 and last 2 size ranges were dismissed after the conversion from corrected scattering data to particle size distribution (PSD) data (Slade \& Boss 2015). Thus PSD between 1.9 and $165 \mu \mathrm{m}$ was calculated using the laser diffraction method and Mie theory, applying the assumption that the measured particles were spherical. The measured variables included temperature, conductivity, pressure, chl a fluorescence (excitation $470 \mathrm{~nm} /$ emission $685 \mathrm{~nm}$ ), turbidity $(700 \mathrm{~nm})$, PSD, and beam attenuation coefficient $\left(c_{p g}, 670 \mathrm{~nm}\right.$ with $5 \mathrm{~cm}$ path length). Optical measurements were proxies for phytoplankton biomass and SPM (Cullen 1982, Spinrad 1986). These measurements were aligned by time stamps, and only down casts (when the instrument package was descending) were used.

To interpret the results from the monthly surveys, it was necessary to differentiate plume water from ambient coastal water unaffected by the discharge. Site P1, at the outfall, was designated as the 'plume' water because it was in the path of the outfall discharge. Stn E, east of the Shi'b Habil submerged reef and $5.2 \mathrm{~km}$ from the outfall, was chosen as the control to represent the 'ambient' coastal water as plume signatures were not detected at this station during our yearlong sampling period. A branching reef north of Stn E apparently blocked the discharge from reaching this region.

Dilution factors (DFs) were calculated to examine the plume's spatial distribution and degree of mixing. Because salinity proved to be consistently higher in the plume than in the ambient water throughout the year (see 'Results: Physical properties and seasonality') and there were no other known sources of high salt content, salinity was used to calculate the DF at each station for each monthly survey as:

$$
\mathrm{DF}=\frac{\left(S_{p}-S_{a}\right)}{\left(S_{X}-S_{a}\right)}
$$

where $S_{p}$ is the maximum salinity at $\mathrm{P} 1, S_{a}$ is the mean salinity of ambient water, and $S_{X}$ is the maximum salinity at the station of interest. Similarly, the plume's vertical distribution was analyzed, where $S_{X}$ is the salinity at a given depth. High DF values indicate low concentrations of the plume, while low DF values indicate a larger contribution of plume water to the measured salinity. These calculations and the ensuing analysis assume that within the space and time scales of these measurements, salinity is essentially conservative.

\section{Statistical analysis}

We applied $t$-tests to compare the water mass characteristics between the plume water measured at P1 and the 'ambient' waters (at Stn E and between P2 and P3, as defined in the first 2 subsections of the 'Results') collected in the AUV survey and monthly surveys. A paired $t$-test was used for the monthly surveys to evaluate whether the water mass characteristics at the outfall (Stn P1) and the ambient water (Stn E) had different seasonal variability. A 5\% threshold for the $\mathrm{p}$-value was used to indicate significance.

\section{Laboratory analysis}

Water samples were obtained from the surface, near the bottom, and at the depth of the chl a maximum (when known) at stations surrounding Shi'b Habil (N, NW, W, S, E, NE) and near the outfall (P1, P2) and were analyzed for chl $a$ and SPM to correlate optical measurements from the FLNTUB and LISST. Water samples were not available for May, July, September, and October of 2014. Water samples for chlorophyll (0.5-2 1, depending on the proximity to the outfall) were filtered through GF/F Whatman ${ }^{\circledR}$ filters and measured using a benchtop fluorometer (Trilogy ${ }^{\circledR}$ Laboratory Fluorometer, Turner Designs) (Arar \& Collins 1997). Samples from the surface waters and $0.5 \mathrm{~m}$ above bottom waters were analyzed for SPM concentration in November and 
December 2014 and January 2015. Water samples (0.5 l) were passed through pre-weighed GF/F Whatman ${ }^{\circledR}$ filters, and then the filters were dried in an oven at $50^{\circ} \mathrm{C}$ for $24 \mathrm{~h}$. After $24 \mathrm{~h}$ in a desiccator, they were reweighed a final time (Grasshoff et al. 2009).

Nutrient concentrations were measured to estimate the daily nutrient loading from the discharge. The estimated discharge rate $\left(42-48 \mathrm{~m}^{3} \mathrm{~s}^{-1}\right)$ was used to calculate the nutrient flux. Surface waters $(100 \mathrm{ml})$ at the outfall (P1), $1.5 \mathrm{~km}$ offshore from the outfall (P7), and around the reef (Stns N, NE, S, NW, and W) were frozen and later analyzed for nitrate, nitrite, phosphate, and silica using US EPA Methods 353.1, 354.1, 365.1, and 370.1, respectively. The detection limits were $2,1,1$, and $5 \mu \mathrm{g} \mathrm{l} \mathrm{l}^{-1}$ for nitrate, nitrite, phosphate, and silica, respectively. Nitrate, nitrite, and phosphate were analyzed using an AAA3 Segmented Flow Analyzer (Seal). Silica was measured using an Aquakem 250 Auto Photo Analyzer (Thermo Scientific). Water from P7 was chosen for comparison with water from P1, because its location $(<1.5 \mathrm{~km}$ from the outfall and $>2.5 \mathrm{~km}$ from the Shi'b Habil submerged reef) ensured that it was less contaminated water and without immediate influence from the reef. Data collected in January, February, August, September, November, and December 2014 were sampled and analyzed in September 2015.

Logistics prevented the analysis of ammonium, which could not be completed on the day collected, and later measurements would not be representative. A nutrient analyzer for urea was unavailable.

\section{Microbial analysis}

Water samples (10 l each) were collected using Niskin bottles for microbial (bacteria and cyanobacteria) analysis, often used as indicators of contamination (Ansari et al. 2015), and also for total nitrogen concentration using the high-temperature catalytic oxidation method with a TOC- $\mathrm{V}_{\mathrm{CPH}}$ analyzer (Shimadzu) (Ansari et al. 2015). Measurements were taken on 3 occasions. The first batch was collected at a depth of $0.5 \mathrm{~m}$ from 4 stations (P1, P2, P4, and P7) on 14 April 2014 (Fig. 1). The next 2 batches were collected at $0.5 \mathrm{~m}$ below the surface and $0.5 \mathrm{~m}$ above the seafloor from the same 4 stations on 15 December 2014 and 29 January 2015. Samples were stored at $4{ }^{\circ} \mathrm{C}$. Two approaches (flow cytometry and highthroughput sequencing) were used to analyze the microbial properties of the plume. Results from these 2 approaches (total cell counts and relative abundance) were multiplied to obtain abundance data.

\section{Flow cytometry}

Cell counts were measured using an Accuri C6 flow cytometer (BD Biosciences). The water samples $(50 \mu l)$ were stained with SYBR Green I (Invitrogen) and incubated for $10 \mathrm{~min}$ at $35^{\circ} \mathrm{C}$ in darkness (Ansari et al. 2015). Differences between the samples were evaluated using a $t$-test.

\section{High-throughput sequencing}

To extract genomic DNA from the samples, water samples (5 l) were filtered through $0.45 \mu \mathrm{m}$ polycarbonate membranes (Millipore), which were stored at $-20^{\circ} \mathrm{C}$. Total DNA was extracted from the membranes using the UltraClean ${ }^{\circledR}$ Soil DNA Isolation Kit (MoBio) and amplified for the 16S rRNA genes with universal forward $515 \mathrm{~F}$ and reverse 909R primers. The amplicons were then submitted for highthroughput sequencing on an Ion Torrent PGM platform (following methods described by Ansari et al. 2015). Sequences that passed the quality check were evaluated for chimeras, and chimera-free sequences were classified according to their taxa using the RDP Classifier, which provided information on the phylogenetic identity (identification to the genus level) (Ansari et al. 2015).

To evaluate the similarity of community composition between samples, multivariate analysis using spatial distance was applied. The relative abundances of the bacterial genera were calculated, collated, and then square-root transformed. Multidimensional scaling (MDS) was performed using Bray-Curtis similarity values of the square-root transformed abundance. Two-way analysis of similarity (ANOSIM; crossed) was used to test whether a significant difference existed in community composition between stations and seasons using Primer v7. A second approach was also conducted based on a protocol described earlier (Harb et al. 2015). Sequence files were sorted based on the ratio of identical sequences to total sequences and identified as unique operational taxonomic units (OTUs). OTUs were prioritized based on criteria shown as title headings in the Appendix, and their identities were determined by best-matching identities (82-97\% similarity over the entire sequenced length of approximately $280 \mathrm{nt}$ ) against the NCBI nucleotide database using the BLASTN algorithm. All Ion PGM sequences are available in the European Nuclear Archive (ENA) Sequence Read Archive (SRA) public repository under accession number PRJEB19774. 
Relative abundance was calculated as the number of sequences of a particular microbial group in a sample divided by the total number of sequences obtained for that sample, after amplification of the bacterial 16S rRNA genes. A $t$-test was used to check if these relative abundances were significantly different at the outfall (see Table 3).

\section{RESULTS}

\section{Physical properties and seasonality}

Data collected from the AUV spatial survey showed that the water discharged from the outfall was characterized by significantly higher surface salinity (40.2 vs. 38.7 PSU), lower temperature $\left(29.2\right.$ vs. $\left.30.3^{\circ} \mathrm{C}\right)$, and higher density (1025.9 vs. $1024.4 \mathrm{~kg} \mathrm{~m}^{-3}$ ) than surface water $1.4 \mathrm{~km}$ away (between Stns P2 and P3). During the echosounder spatial survey, acoustic profiling revealed a density discontinuity between the shallower ambient coastal water and the denser, and hence deeper, saline effluent (Fig. 2a).

Surface temperature at the discharge (Stn P1) and offshore (Stn E) increased from March to October, and then decreased to minimal temperatures in February (Fig. 3a). The seasonality of plume temperature paralleled that of ambient coastal water, except when the plume temperature plummeted to nearly $5^{\circ} \mathrm{C}$ below ambient temperature in February (Fig. 3a). In contrast, plume salinity exceeded ambient salinities, and peaked at 48 PSU in June, 10 PSU higher than the ambient salinity (Fig. 3b, Table $1 ; \mathrm{p}<$ 0.001, $\mathrm{df}=499, t=56$ ). Ambient surface salinity never exceeded 39.3 PSU, and

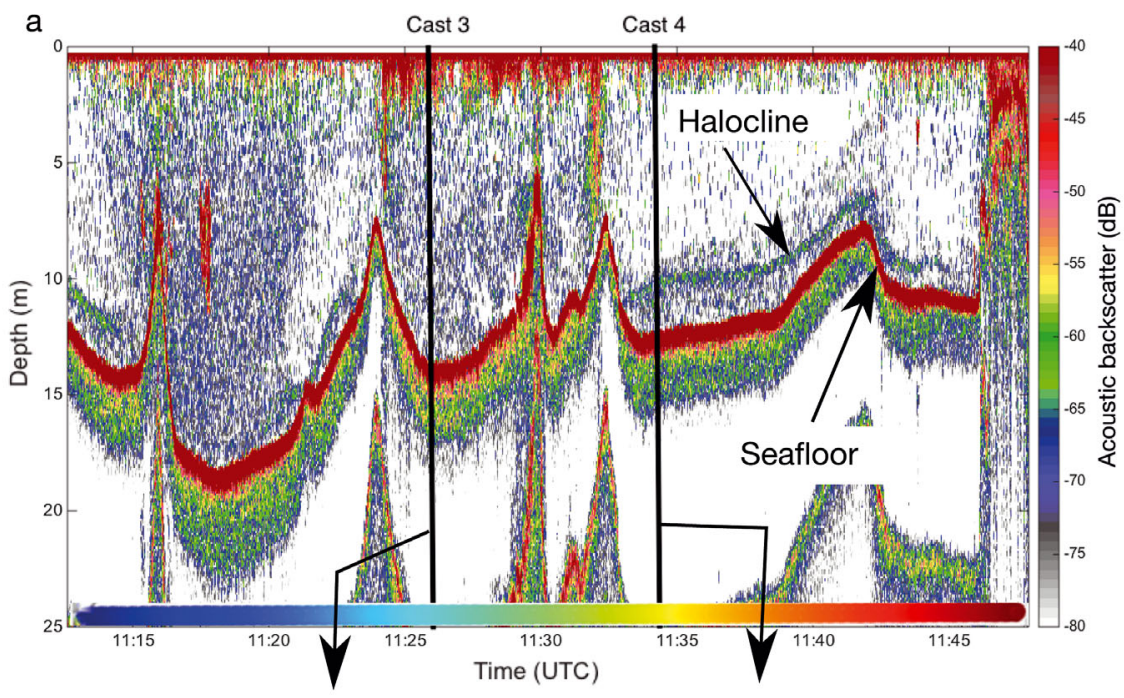

b
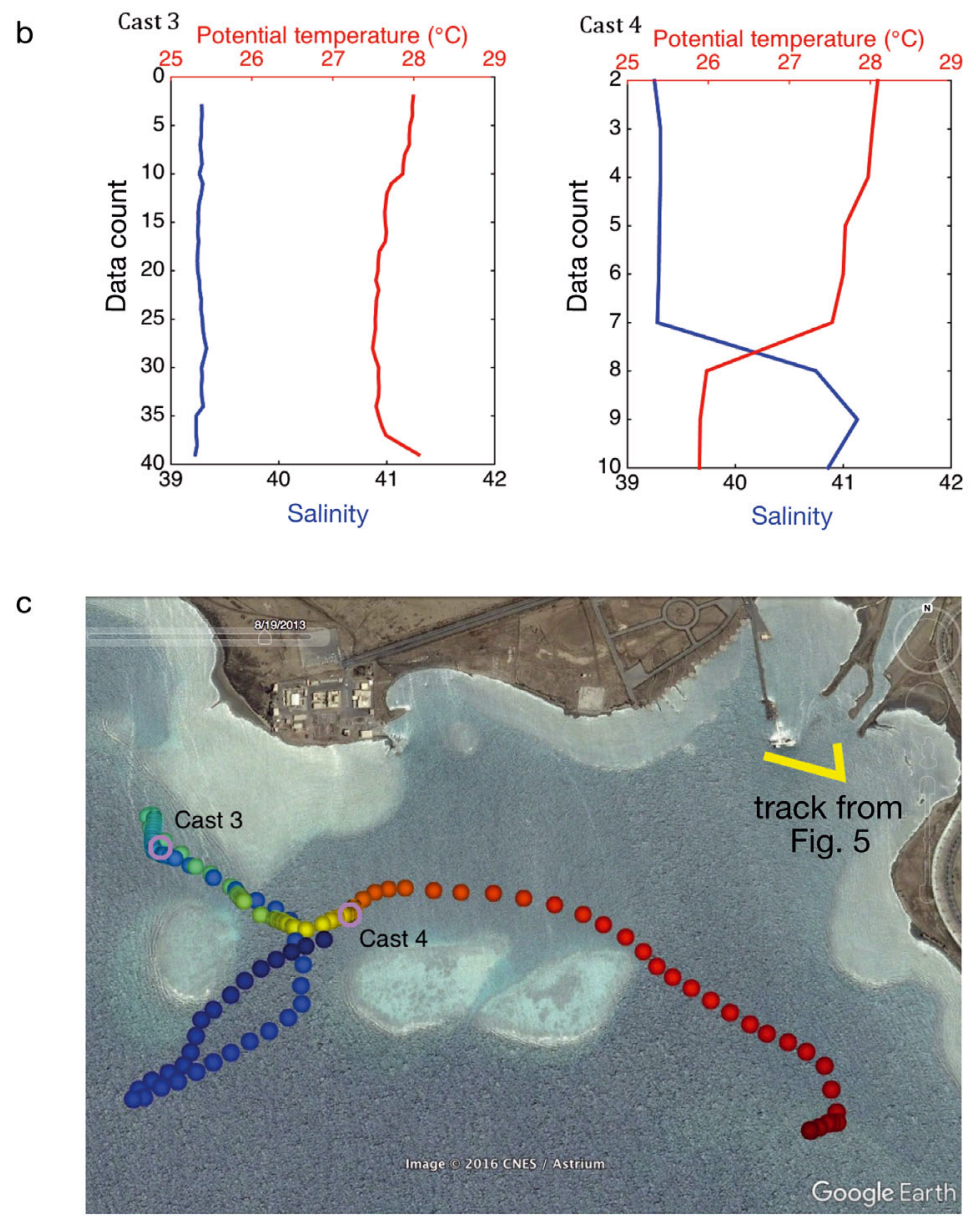

Fig. 2. (a) High-resolution echogram taken $>1 \mathrm{~km}$ from the outfall illustrates areas along the coast of Al-Lith where the plume signal is present and absent. The halocline signal illustrates the presence of the plume. Casts were taken at Stns P5 and P6 (casts 4 and 3, respectively), with (cast 4) and without (cast 3) the plume signals as labeled in (a). (b) Salinity and temperature profiles show a high salinity signal in cast 4 but not in cast 3, supporting the sharp salinity gradient (halocline) seen in the echosounder data in (a). Vertical axes show data counts (i.e. the number of samples from the start of sampling at the surface towards the bottom) as a proxy for depth because pressure measurements were not available (see 'Materials and methods: Spatial survey'). (c) Echosounder path and locations of casts 3 and 4 ; the color scheme above the $x$-axis (time) in (a) corresponds to the spatial position of the colored path in the map. The track for the echogram in Fig. 5 is also shown in the map 

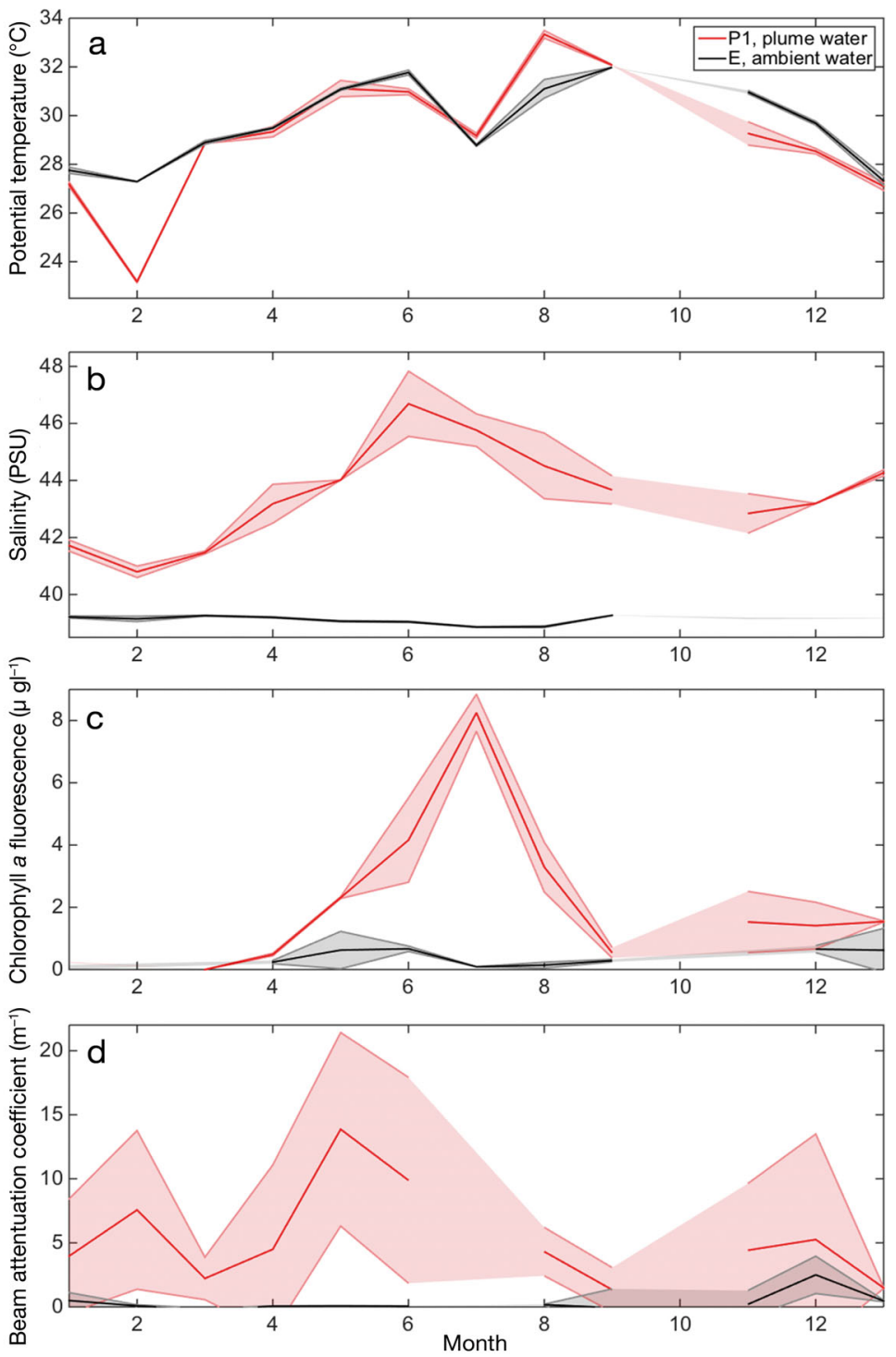

Fig. 3. Mean (solid line) and SD (shaded area) plotted for (a) potential temperature, (b) practical salinity, (c) chlorophyll a concentration derived from fluorescence, and (d) beam attenuation coefficient $\left(c_{p g}\right)$. Data were collected at Stns P1 (red) and E (black) from January 2014 to January 2015. No fieldwork was conducted in October, which resulted in a gap in data for all 4 variables above. In addition, the laser diffractometer (LISST) was not deployed in July for logistical reasons, resulting in a gap in $C_{p g}$ data for July

Table 1. Salinity, density, chlorophyll $a$, and the beam attenuation coefficient $\left(c_{p g}\right)$ of the discharge water (Stn P1) compared to the ambient coastal reef water at Stn E (see Fig. 1 for station locations), given as mean \pm SD. Significant differences between plume and ambient water $(p<0.05)$ are shown in bold

\begin{tabular}{|c|c|c|c|c|c|}
\hline & $\begin{array}{c}\text { Temperature } \\
\left({ }^{\circ} \mathrm{C}\right)\end{array}$ & $\begin{array}{l}\text { Salinity } \\
\text { (PSU) }\end{array}$ & $\begin{array}{l}\text { Density } \\
\left(\mathrm{kg} \mathrm{m}^{-3}\right)\end{array}$ & $\begin{array}{c}\text { Chl a } \\
\left(\mu \mathrm{g} \mathrm{l}^{-1}\right)\end{array}$ & $\begin{array}{c}C_{p g} \\
\left(\mathrm{~m}^{-1}\right)\end{array}$ \\
\hline Plume & $30( \pm 2.4)$ & $44( \pm 1.7)$ & $1027.7( \pm 4.2)$ & $1.9( \pm 1.5)$ & $4.7( \pm 5.6)$ \\
\hline Ambient & $30( \pm 1.6)$ & $39( \pm 0.14)$ & $1023.3( \pm 4.9)$ & $0.45( \pm 0.41)$ & $0.41( \pm 0.81)$ \\
\hline $\mathrm{p}$ & 0.19 & $<0.001$ & $<0.001$ & $<0.001$ & $<0.001$ \\
\hline
\end{tabular}

plume salinity was never observed below 40.5 PSU. During the yearlong study, no evidence of a strong cross-shelf salinity gradient was observed apart from the near coastal plume/ambient transition. Thus, the primary indicator of plume dilution was the salinity gradient. Because of its higher salinity, plume density always exceeded ambient seawater density during our sampling period (Table 1; $\mathrm{p}<0.001$, df = 552, $t=8.7$ ).

\section{Optical properties and seasonality}

The AUV spatial survey demonstrated that water discharged from the outfall was characterized by higher chl a (0.8 vs. $0.6 \mu \mathrm{g} \mathrm{l}^{-1}$ ) and higher turbidity (2.3 vs. 0.15 NTU) than surface water $\sim 1 \mathrm{~km}$ away (between P2 and P3). Subsequent monthly surveys revealed that the plume routinely contained higher chl $a$ and had higher $c_{p g}$ values than the surrounding environment (Table 1), and exhibited greater seasonal variability (Fig. 3c,d). In fact, chl a fluorescence values in the plume peaked at more than an order of magnitude higher than the ambient water in July (Fig. 3c). The $c_{p g}$ of plume waters peaked in May, with secondary peaks during winter (December and February). A slight elevation in the ambient $c_{p g}$ was observed in December only (Fig. 3d). The decoupling of the $c_{p g}$ and chl a fluctuations suggests that the January peak in $c_{p g}$ is due to non-algal particles (data on fluorescence were not available for February).

Data collected at the outfall (P1) in January, April, August, and November were chosen to show the seasonal patterns in PSD of plume waters for winter, spring, summer, and autumn, respectively (Fig. 4). During the winter, PSD of the top half of the water column and the bottom half of the water column were similar in magnitude and shape (Fig. 4a). In the spring, the surface waters contained lower volume concentrations of the pico- (size $<2 \mu \mathrm{m})$ and nano-particles $(2-20 \mu \mathrm{m})$, but a peak in the micro-particles (20-200 $\mu m_{\text {; }}$ Fig. 4b). The bottom water during spring had a higher magnitude of the same PSD pattern. During the summer, this trend reversed, and the sur- 

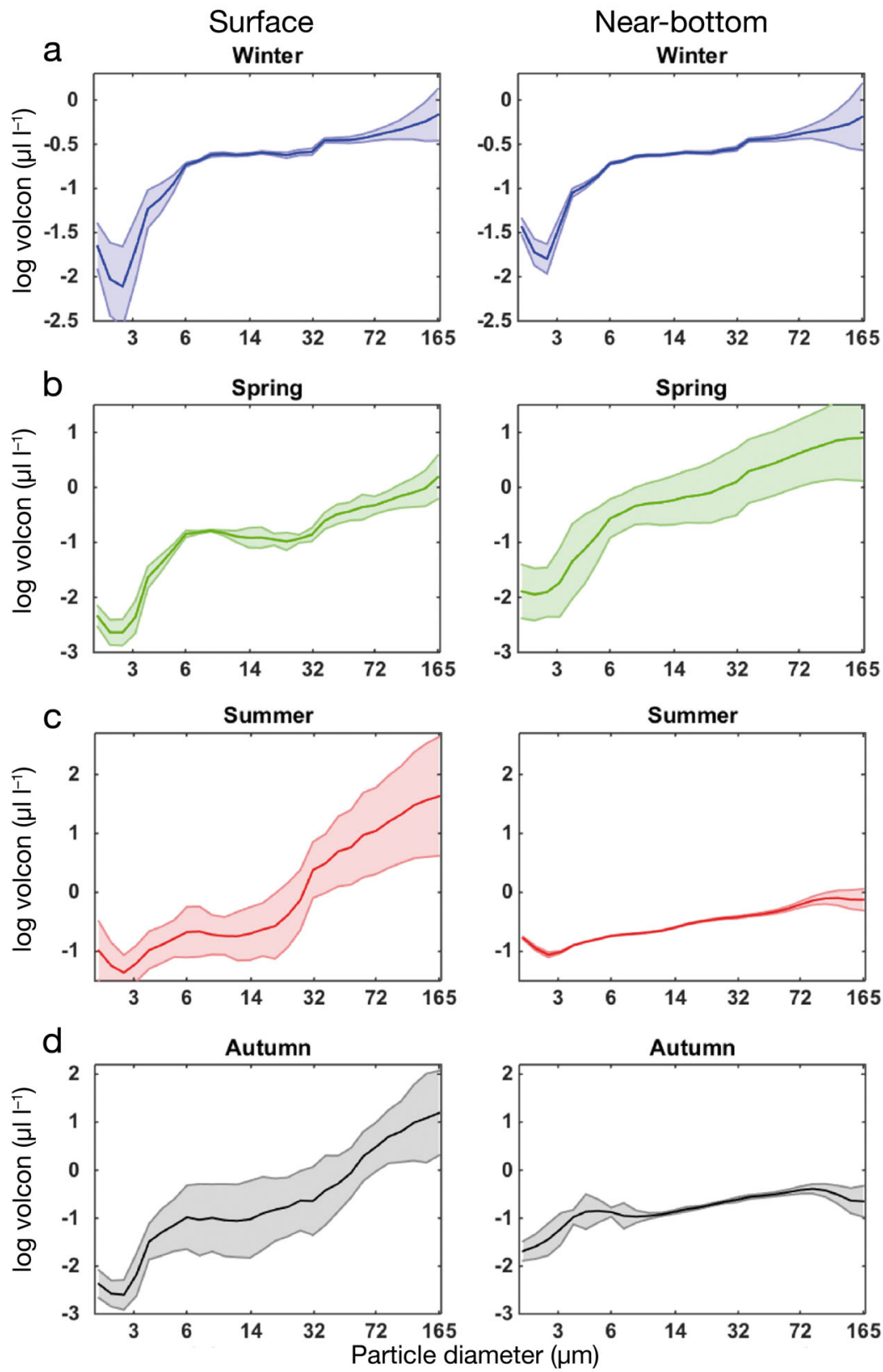

Fig. 4. Mean (solid line) and SD (shaded area) of volume concentration (volcon) plotted against particle diameter for surface (left column) and bottom (right column) water to illustrate the difference between depths at Stn P1. January, April, August, and November data are shown to represent (a) winter, (b) spring, (c) summer, and (d) autumn

face waters had a higher volume concentration (>70fold) than the bottom waters (Fig. 4c); as in spring, both layers had low pico- and nano-particles but peaks in micro-particles. In autumn, the bottom water had much lower volume concentrations than the surface water (Fig. 4d).

Volume concentrations at Stn P1 were significantly higher than at Stn E (up to 80 times higher in August) during our sampling period. During all seasons, the volume concentrations at Stn E was nearly negligible $(<<0.5 \mu \mathrm{g}$ $\mathrm{I}^{-1}$ ), and approached the detection limit of the LISST (data not shown).

SPM concentration showed no significant correlation with the $c_{p g}$ data measured by LISST, possibly because particle concentrations away from the discharge were below the LISST limit of detection for the $5 \mathrm{~cm}$ path length. SPM was lowest at the stations close to the reef and highest at the intermediate stations (P5 and P7) rather than the stations near the outfall (P1, P2, P3, P4, and P8), but with no statistical significance $(p>0.1)$. SPM at a station northeast of the Shi'b Habil submerged reef (Stn NE), $3.8 \mathrm{~km}$ from the outfall, was a magnitude lower than at a station 2.3 $\mathrm{km}$ closer to the outfall (P7). Insufficient samples were analyzed to evaluate the seasonal variability of SPM.

\section{Plume trajectory}

The spatial survey using the echosounder showed that the turbid effluent occupied nearly the entire water column near the outfall and then submerged to near-bottom waters approximately $250 \mathrm{~m}$ offshore (Fig. 5). This pattern is consistent with the AUV survey obtained $\sim 6$ wk prior, which revealed that the dense plume disappeared from the surface layer $(0-1 \mathrm{~m})$ approximately $250 \mathrm{~m}$ offshore from the outfall. The plume bottom layer (Fig. 2a) was readily observed by a sharp salinity gradient in the CT casts (39.3 PSU in the ambient water and 41.2 PSU in the effluent plume; Fig. 2b). Because density interfaces, in this case driven by the halocline, show up as acoustic signals, the salinity gradient from the cast is presumably related to the boundary of the acoustic backscatter signal $(\sim 10 \mathrm{~m})$. The temperature and salinity profiles at P6 and P5 (numbered casts 3 and 4, respectively; Fig. 2) illustrate that plume dispersion was blocked by the topographic sill separating the 2 sites (Fig. 2a,b). The turbid effluent followed the bathymetry, creating a 1-3 $\mathrm{m}$ thick layer on the seafloor (Fig. 5). 


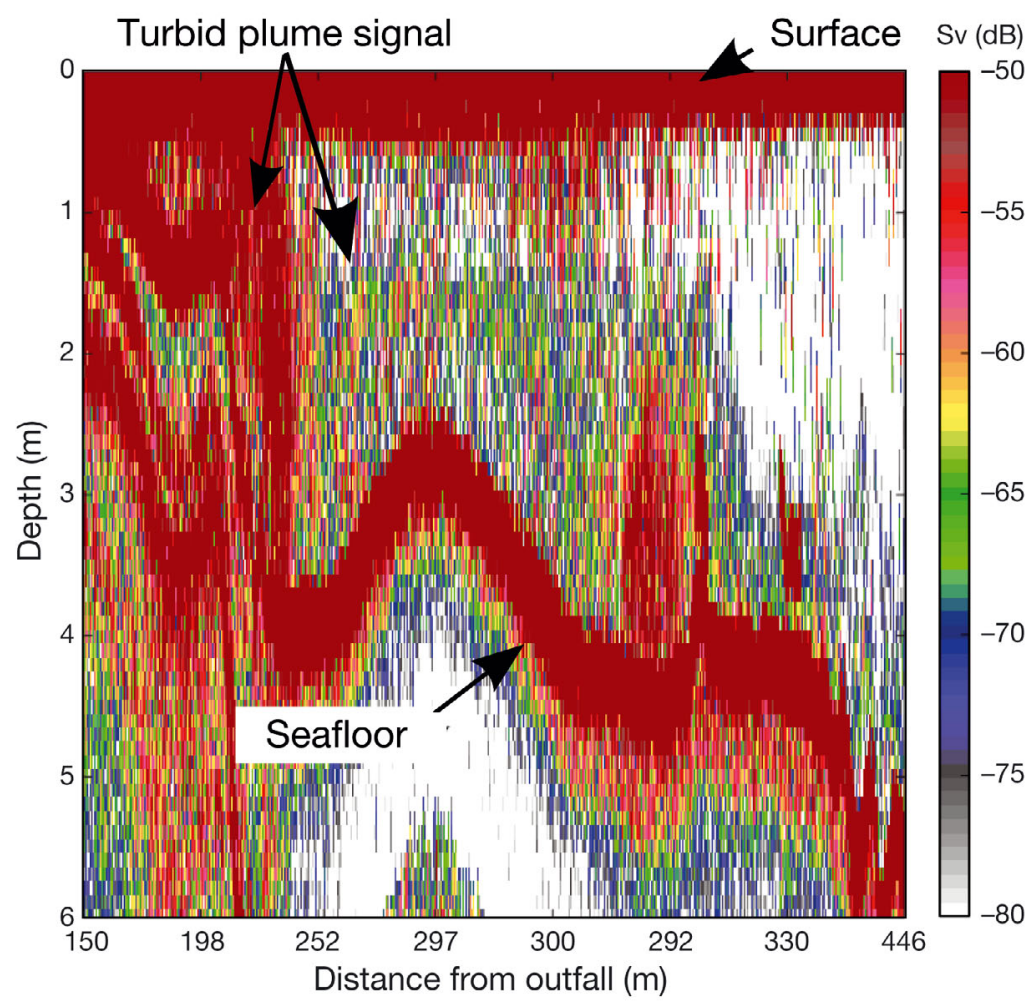

Fig. 5. High-resolution echogram measured $\sim 300 \mathrm{~m}$ from the outfall shows the plume's turbid signal leaving the surface to form a layer above the bottom. Fig. 2c shows where this echogram was taken

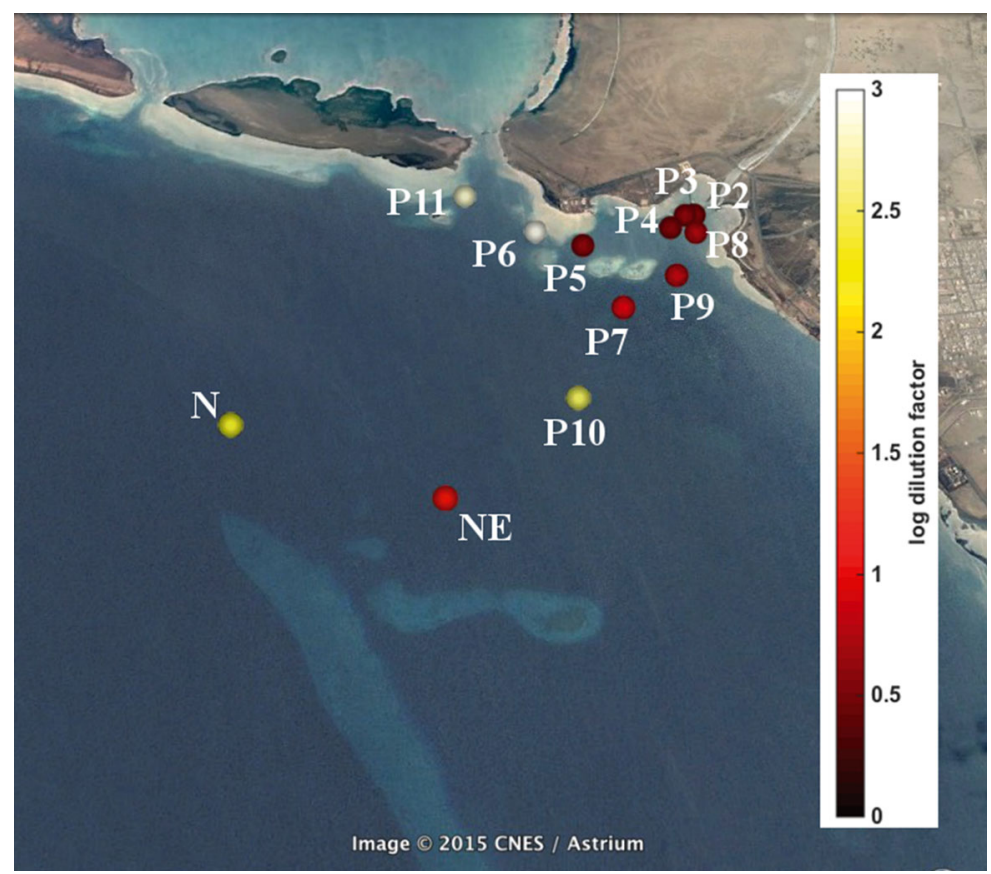

Fig. 6. Median of all monthly log dilution factors (DFs) of the effluent. The lower log DFs (dark red) represent waters with higher plume concentrations. DF increases with distance from the outfall as expected, but is still present at Stn N, $4.7 \mathrm{~km}$ away, suggesting that the plume from the outfall could have an effect on the submerged reef at Shi'b Habil
Monthly surveys revealed that the 1-3 $\mathrm{m}$ thick near-bottom plume layer experienced lower mixing and diffusion (lower $\mathrm{DF}_{\text {; }}$ higher concentration of discharge water) than surface waters. The lowest DFs occurred $0.25,0.3$, and $0.5 \mathrm{~km}$ offshore from the outfall (P2, P3, and P4, respectively) while DFs near the lagoon outfall, at 1.7 and $2.3 \mathrm{~km}$ from the outfall (P6 and P11, respectively), were the highest observed (Fig. 6). The topographic sill blocked the near-bottom discharge plume from spreading into the area south of the lagoon (P6 and P11), as observed in the echosounder survey (Fig. 2b). The effluent extended to the northern side of the Shi'b Habil submerged reef, 4.7 and $3.8 \mathrm{~km}$ away from the outfall (Fig. 6; Stns $\mathrm{N}$ and $\mathrm{NE}$, where bottom depths are 40 and $20 \mathrm{~m}$, respectively). The diluted plume was observed at mid-water $6.4 \mathrm{~km}$ away from the outfall (Stn NW) in August and September, identified by high salinity peaks (Fig. 7), and as far as $8 \mathrm{~km}$ from the outfall (Stn W) in September only. In July and November, salinity increased near the seafloor, indicating the diluted plume travelled $6.4 \mathrm{~km}$ from the outfall as a bottom layer (Fig. 7). Other months had relatively homogenous salinity profiles, suggesting the diluted plume was absent during these months.

\section{Nutrient concentrations}

Nutrient concentrations at the discharge (P1) were significantly higher than concentrations about $\sim 1.4 \mathrm{~km}$ offshore (P7) (Table 2). Silica concentrations were highest in August, nitrate and nitrite were highest in December, and phosphate was highest in late January (Fig. 8). The total nitrogen concentrations at P1 were significantly higher ( $>4$-fold) than at P2, P4, and P7. Consistent with the dilution distribution, near-bottom nutrient concentrations northeast of Shi'b Habil (Stn NE), $3.8 \mathrm{~km}$ away from the outfall, were similar to concentrations in surface waters at the outfall (P1) and higher than those at the stations near Shi'b Habil (NW, W, S, and N) ( $\mathrm{p}=$ 0.48-0.75, df $=6, t=0.34-0.75$ ). With an estimated volume discharge of $42-48 \mathrm{~m}^{3}$ 
Table 2. Results of $t$-test comparing surface nutrient concentrations $\left(\mu \mathrm{mol} \mathrm{l}^{-1}\right.$, mean $\left.\pm \mathrm{SD}\right)$ between the discharge water (Stn P1) and water $1.4 \mathrm{~km}$ from the outfall (Stn P7, see Fig. 1 for station locations). Significant differences between plume and ambient water $(p<0.05)$ are shown in bold

\begin{tabular}{|lcccc|}
\hline & Silica & Nitrate & Nitrite & Phosphate \\
\hline Plume & $8.6( \pm 3.1)$ & $2.2( \pm 2.1)$ & $2.2( \pm 2.1)$ & $1.1( \pm 0.51)$ \\
Ambient & $1.7( \pm 2.0)$ & $0.37( \pm 0.60)$ & $0.46( \pm 0.70)$ & $0.17( \pm 0.24)$ \\
$\mathrm{p}$ & $<\mathbf{0 . 0 0 1}$ & $\mathbf{0 . 0 4 9 7}$ & $\mathbf{0 . 0 4 8 3}$ & $\mathbf{0 . 0 0 1 5}$ \\
\hline
\end{tabular}

$\mathrm{s}^{-1}$, the daily nutrient fluxes from the discharge are $109-123 \mathrm{~kg} \mathrm{~d}^{-1}$ for nitrate-N, $72-82 \mathrm{~kg} \mathrm{~d}^{-1}$ for nitrite$\mathrm{N}, 121-138 \mathrm{~kg} \mathrm{~d}^{-1}$ for phosphate-P, and 882-999 kg $\mathrm{d}^{-1}$ for silica-Si.

\section{Microbial communities}

Microbial communities were measured at 4 stations on 3 different occasions. Because the effects of

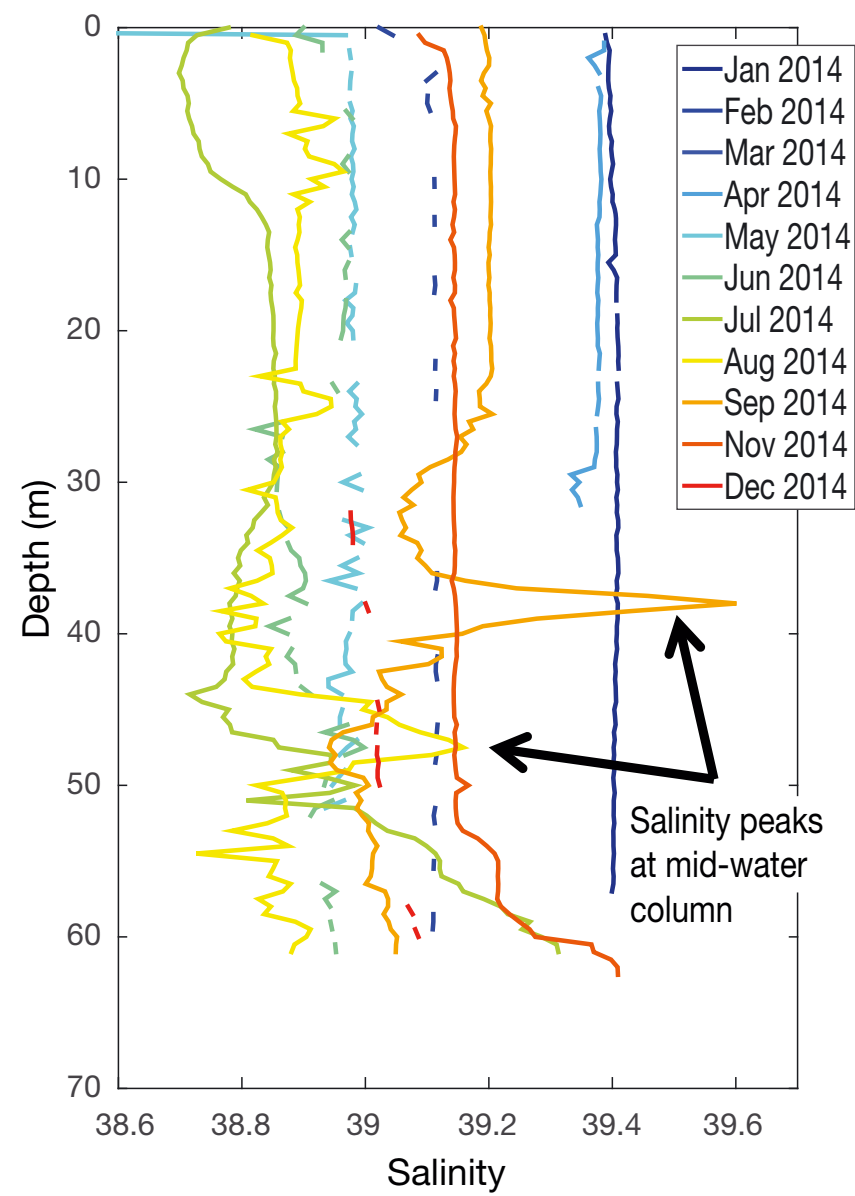

Fig. 7. Salinity profiles at Stn NW (see Fig. 1) during monthly surveys from January to December 2014. Arrows indicate salinity peaks in August and September location and season are expected to influence microbial community composition, a 2-way ANOSIM was performed. Results showed significant clustering according to month $(\mathrm{R}=0.86$, $p=0.001)$ and indicated that April, December, and January all have significantly different microbial communities (Fig. 9a). Although microbial composition differed significantly between locations $(R=0.48, \mathrm{p}=0.024)$ the seasonal influence was stronger (Fig. 9a). One-way ANOSIM revealed no significant difference between surface and bottom waters $(R=0.015, \mathrm{p}=$ $0.361)$; however, the bottom water communities at P2, P4, and P7 were more similar to the P1 samples than their corresponding surface water communities (Fig. 9a). Unclassified Actinomycetales, unclassified Microbacteriaceae, and unclassified Micrococcineae accounted for much of the difference between P1 and the other stations in the MDS plot (Fig. 9a). Table 3 lists genera associated with opportunistic pathogenic species, twelve of which were present at the outfall (P1). Arcobacter sp. was found in significantly higher abundance at P1 than at the other stations (Table 3).

The bacterial and cyanobacterial abundance at the outfall (P1) were distinct from 3 other stations (P2, P4, and P7). Total cell counts were significantly higher in the surface water at P1 than at P2, P4, and P7 ( $p<$ $0.05)$, and in the bottom water at P1 than at P2 and P7 $(p<0.001)$, and P4 $(p=0.01)$. We found no significant difference between the cell counts at P2, P4, and P7 $(p>0.05)$, except that P4 was lower than P7 ( $p=0.01)$. Species richness (OTU count) did not vary significantly among the stations. Certain OTUs were significantly more abundant inside the discharge outfall (P1) (Appendix).

Abundance of microbial groups varied with the distance from the outfall (Fig. 9b). A complete list of OTUs with higher abundance at P1 than at P2, P4, and $\mathrm{P} 7$ is provided in the Appendix. Bacteroidetes and Actinobacteria had the highest abundance at P1, and decreased in abundance from P1 to P7. By contrast, Cyanobacteria (Prochlorococcus) were least abundant at P1, and most abundant at P7 $(1.4 \mathrm{~km}$ away from P1).

\section{DISCUSSION}

\section{Dense, saline plume}

The shallow aquaculture ponds are exposed to high solar radiation in the summer, resulting in high evaporation rates that yield extremely high salinity. 
Table 3. Abundance $\left(\mathrm{ml}^{-1}\right)$ of genera associated with opportunistic pathogens present at the different stations (P1, P2, P4, P7) and the pvalues ( $t$-test) for testing their abundance in the outfall (P1) compared to the other stations. Arcobacter abundance is significantly higher (indicted by bold type) at P1 than at the other sampled stations

\begin{tabular}{|lllclc|}
\hline Genus & P1 & P2 & P4 & P7 & p \\
\hline Acinetobacter & 325451 & 250 & 25087 & 42129 & 0.234 \\
Arcobacter & 196983 & 16989 & 16898 & 3663 & $\mathbf{0 . 0 2 2}$ \\
Aeromonas & 8564 & 36809 & 88390 & 1832 & 0.239 \\
Bacteroides & 17129 & 12 & 23397 & 1832 & 0.241 \\
Bacillus & 8565 & 5663 & 3900 & 1832 & 0.223 \\
Enterococcus & 25694 & 8494 & 12999 & 0 & 0.572 \\
Legionella & 0 & 0 & 0 & 0 & 0.374 \\
Escherichia/Shigella & 0 & 8494 & 10399 & 0 & 0.181 \\
Mycobacterium & 42823 & 16989 & 11699 & 1832 & 0.576 \\
Pseudomonas & 882143 & 641319 & 503045 & 100744 & 0.271 \\
Staphylococcus & 8565 & 0 & 0 & 1832 & 0.629 \\
Streptococcus & 282629 & 189706 & 162482 & 10990 & 0.433 \\
\hline
\end{tabular}

increase from 41 to 50 PSU. Therefore, the saline aquaculture effluent has the potential to reduce the coral species diversity in the region surrounding the discharge.

Past studies of desalination plants show that brine discharges elevate salinity above the ambient conditions (Winters et al. 1979) and alter the community structures of corals, seagrass, and soft-sediment ecosystems that lie within the footprint of the plume (Roberts et al. 2010). In the cited cases, salinity returned to the background levels within $0.01-4 \mathrm{~km}$ of the outfall. In the case of Al-Lith's aquaculture discharge, the salinities at Stns N and NE (4.7 and $3.8 \mathrm{~km}$ from the outfall) were routinely 0.5 and 2 PSU, respectively, above ambient salinities. Therefore, the impact zone of the Al-Lith aquaculture facility discharge has a larger footprint than the previously studied brine dis-

The observed maximum salinity of the plume ( 48 PSU) was on the higher extreme limits of coral tolerances, although high salinity-tolerant corals in the Red Sea and the Arabian Gulf have survived salinities up to 50 PSU (Coles 1988, 2003). From a study along the coast of Bahrain, Sheppard (1988) estimated that 1 coral species is lost per salinity unit charges. Furthermore, the effluent was observed in the mid-water column at Stns NW and W in September, 6.4 and $8 \mathrm{~km}$ from the outfall, respectively. The mid-water column position is consistent with the dynamics of dense plumes reaching a density equilibrium following an initial buoyancy-driven mixing phase (Snider \& Andrews 1994).
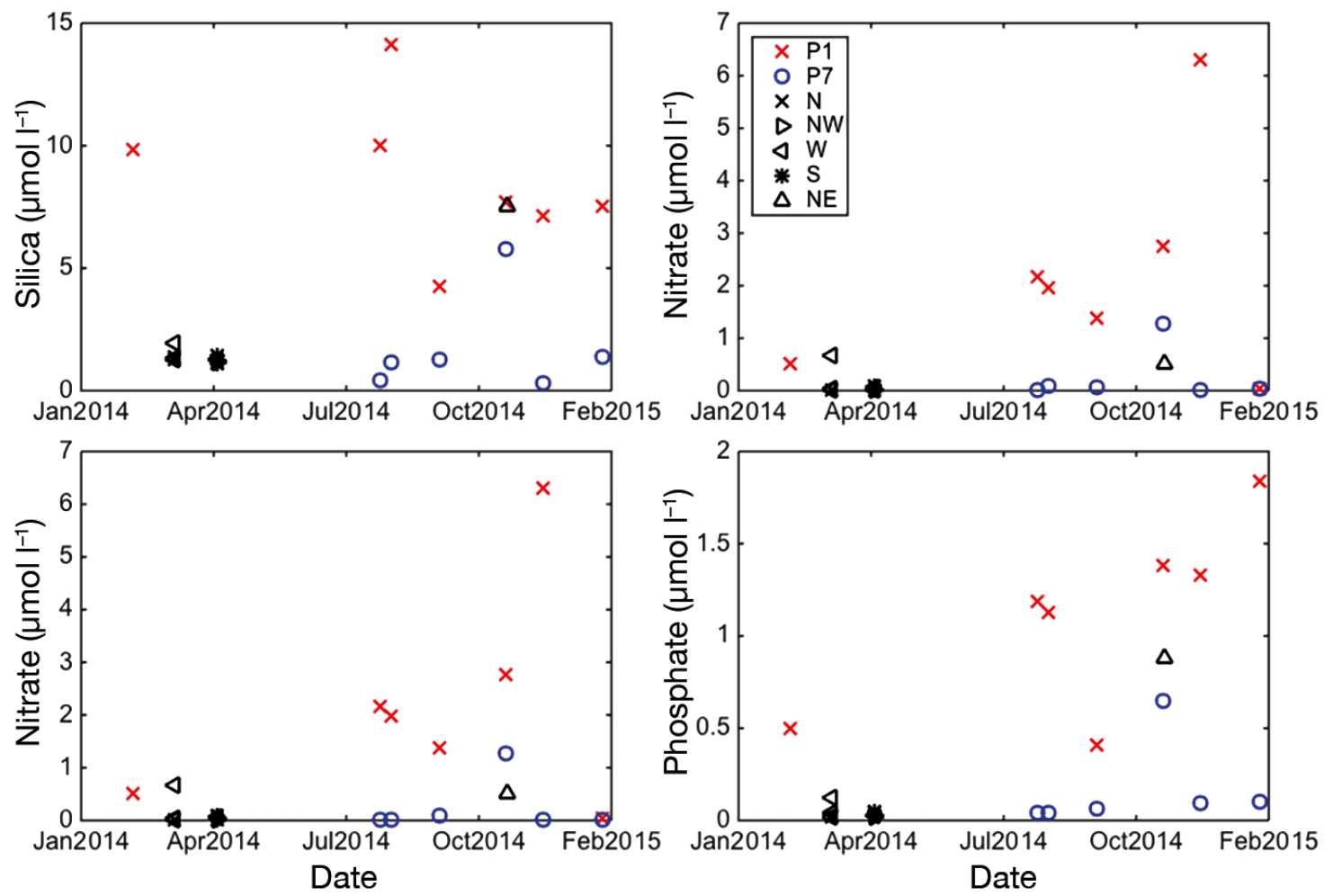

Fig. 8. Surface nutrient concentrations of silica, nitrate, nitrite, and phosphate measured over the sampled months at Stns P1 (red) and P7 (blue), and at Stns N, NW, W, S, and NE on Shi'b Habil (black) 

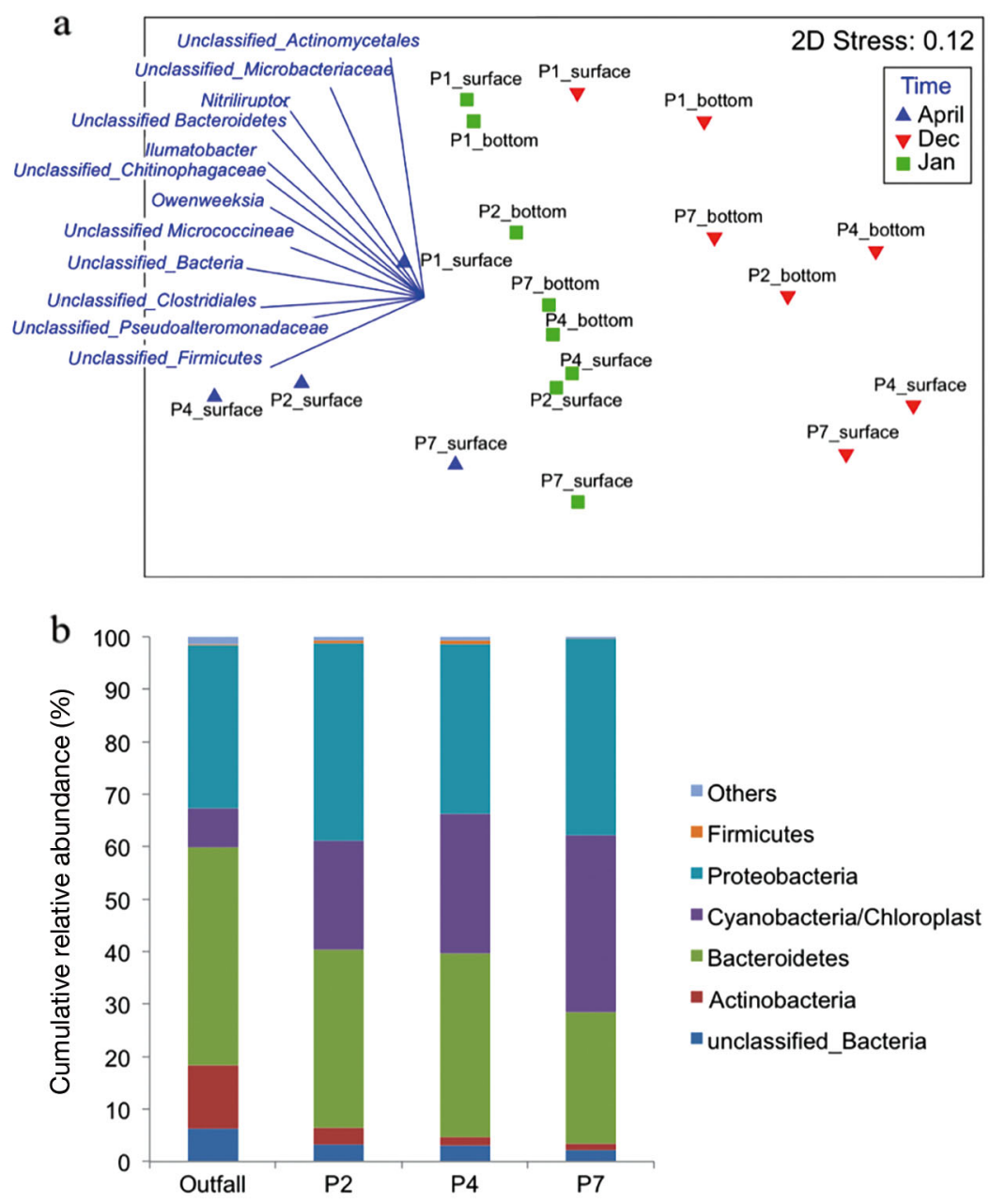

Fig. 9. (a) Multi-dimensional scaling plot based on Bray-Curtis dissimilarities of microbial communities among seasons (April, December, January) by station (P1 to P7, see Fig. 1) and water depth (surface and bottom water). Arrows indicate significantly correlated bacterial taxa; arrow length is proportional to the strength of the correlation. Data were square-root transformed. (b) Cumulative relative abundance of bacterial phyla at selected stations (outfall $=$ Stn P1)

The acoustic survey revealed steep topographic features that obstruct and channel the plume's trajectory (Fig. 2a). The monthly surveys that followed documented that the plume did not reach Stns P6 and P11, sites north of the sill, suggesting this initial observation holds true throughout our yearlong sampling period. The dense effluent likely disperses along the topographic slopes and forms pools in topographic pockets and depressions. High-resolution bathymetric surveys are needed to map out these depressions in the seabed. Detailed bathymetric maps would enable the evaluation of likely pathways and the spatial extent of the dense saline plume.

Nutrients, sediment loads, and toxins from slowflushing sewage wastewater detrimentally affect corals (Pastorok \& Bilyard 1985). Pastorok \& Bilyard (1985) found that corals were outcompeted by benthic algae, their regrowth was repressed, and oxygen levels decreased. Similar ecological changes could occur where the discharge plume pools in topographic pockets in the region. Without knowing the exact bathymetry of the coastal waters of Al-Lith, it is currently difficult to predict what will be a potential improvement, and we prefer not to speculate on this point.

\section{Nutrient-rich productive plume}

Due to regulations, each pond must be emptied and dried for at least 1 mo every year; thus after the last harvest, usually by February, the ponds are drained and sediments are oxidized before the new harvest season begins in April and May (N. Ayaril pers. comm.). The aquaculture facility aims for 3 harvests $\mathrm{yr}^{-1}$, and after each harvest the ponds are flushed and refilled. The exact timing of pond flushing is unknown, and perhaps varies between years. Harvest cycles of the shrimp ponds suggest that the highest discharge of silica will follow the flushing of the ponds in early summer, end of summer, and mid-winter. Silica concentration at the outfall (P1) was highest $\left(10-14 \mu \mathrm{mol} \mathrm{^{-1 }}\right)$ in August, and decreased to less than one-third that amount in September (Fig. 8). Apart from these 2 extremes, silica in the discharge showed no distinct seasonality. Higher temporal resolution of nutrients at the outfall and additional operational details about the aquaculture ponds, including chemical characteristics of these ponds, are necessary to resolve the impact of operational cycles on the discharge volume and compositional characteristics.

Sediments flushed from the ponds are a likely cause of the significantly higher silica concentration in the plume (Fig. 8). Increased silicate, along with the available nitrogen and phosphorus, may facilitate diatom growth and cause a shift to a diatom-dominated phytoplankton community (Brzezinski 1985, Dugdale \& Wilkerson 1998). Since diatom-rich material sinks faster following nutrient depletion, it may increase the depositional flux of organic matter, pro- 
viding more biomass for decomposition in the seafloor sediment (Richardson \& Cullen 1995, Turner et al. 1998) and increase both infaunal and microbial activity (Simon et al. 2002).

The aquaculture operations evidently contributed to the plume's distinct biological characteristics. The discharge water contained higher chl a content (Fig. 3c), and SPM, indicated by $c_{p g}$ (Fig. 3d), than the surrounding water. The increased SPM is likely organic material (e.g. excess feed or animal parts) from the aquaculture operations. As expected from other studies that saw high nutrient concentrations in aquaculture plumes (Ackefors \& Enell 1994), the significantly higher nitrogen and phosphorus content that we observed (Fig. 8, Table 2) is likely derived from decomposing organic waste and residual feed. Thus the discharge water provides nutrients for primary productivity in an otherwise oligotrophic sea. This nutrient load likely contributes to the high chl a concentrations observed in spring and summer that spanned the period from April to December. The peak chl a concentration was an order of magnitude higher than the ambient chl a peak (Fig. 3c). Yet chl $a$ values observed (0-8 $\mu \mathrm{g} \mathrm{l}^{-1}$ ) were much lower than aquaculture effluents in Hawaii $\left(35.8 \mathrm{~g} \mathrm{l}^{-1}\right.$; Ziemann et al. 1992) and Florida (>50 $\mu \mathrm{g} \mathrm{l}^{-1}$; Shireman \& Cichra 1994). Higher chl a fluorescence relative to $c_{p g}$ at Stns P5 and P7 suggests that sufficient time and distance have elapsed from the initial discharge point to allow phytoplankton to grow within the plume. Nutrient-limited phytoplankton can respond as rapidly as within $1 \mathrm{~d}$ to measurable nutrient input (D'Elia et al. 1986).

\section{Microbial community}

Bacterial and cyanobacterial communities at the outfall and $0.25 \mathrm{~km}$ from the outfall (P1 and P2) were significantly impacted by the aquaculture plume. Its effects were less evident at stations 0.5 and $1.5 \mathrm{~km}$ from the outfall (P4 and P7).

The more abundant microbial groups in the plume are characteristic of coastal runoff water. Specifically, some microbial groups that are significantly more abundant at the outfall (P1) $(\mathrm{p}<0.05)$ than at more distant stations are species that have been found in a hypertrophic lake (Rhodoluna lacicola), marine sediments (Loktanella agnita, Sediminocola luteus), contaminated water (Alkaliphilus sp.), and Pacific tropical seawater (Gracilimonas rosea) (Takai et al. 2001, Ivanova et al. 2005, Cho et al. 2013, Hahn et al. 2014). Additionally, OTUs previously isolated from fresh- water eutrophic ponds (Aquiluna rubra), solar salterns (Pontimonas salivibrio), near hydrothermal vents (Alteromonas sp.), and freshwater sediment (Solitalea koreensis) (Ivanova et al. 2004, Van Trappen et al. 2004, Hahn 2009, Weon et al. 2009, Jang et al. 2013) were 5-fold more abundant at $P 1$ than at other stations, with $>428 \times 10^{4} \mathrm{ml}^{-1}$ abundance. Some species were only present at P1, with abundance $>8.5 \times 10^{4} \mathrm{ml}^{-1}$, including species previously identified in rivers and streams flowing through siliceous substrates (Calothrix desertica), estuarine sediment (Illumatobacter fluminis), marine sediment and sea snails (Lewinella persica), and frozen sand from the upper littoral zone (Crocinitomix catalasitica) (Bowman et al. 2003, Khan et al. 2007, Berrendero et al. 2011). One genus, Arcobacter, which is associated with opportunistic pathogenic species, was significantly more abundant $(\mathrm{p}<0.05)$ at P1 than at the other stations. Species from this genus, e.g. A. butzleri, could be pathogenic to some animals, including humans. In contrast to the discharged wastewater at P1, the microbial community $1.5 \mathrm{~km}$ offshore at P7 was typical of oligotrophic coastal waters, with a higher abundance of the genus Prochlorococcus, which has been observed processing organic nitrogen in oligotrophic regions of the Arabian Sea (Zubkov et al. 2003) and is a significant component of the phytoplankton in the Red Sea (Kheireddine et al. 2017).

\section{CONCLUSIONS}

The characteristics and variability of wastewater from the Red Sea's largest aquaculture facility were measured, providing information regarding its potential environmental impact. This study is the first to unveil the potential modifications of seawater as it passes through the integrated aquaculture facility in Al-Lith. Contributions from other local discharges to Al-Lith's coastal ecosystem were not evaluated, but compared to the ambient coastal waters, the aquaculture plume was significantly more saline and dense, contributed to a longer and greater spring chlorophyll bloom, contained more nitrate, nitrite, phosphate, silica, and SPM, and had a distinct microbial community. In addition, its impact zone was larger than those of previously studied brine discharges and routinely reached stations that were $4.7 \mathrm{~km}$ from the outfall, with plume signals observed as far from the discharge point as $8 \mathrm{~km}$.

Because the plume is a dense, bottom-flowing layer, future ecological surveys should evaluate its 
impact on benthic and demersal communities. The coral, seagrass, and mangrove cover of a greater range must be evaluated to assess the broader effects of the outfall along varying gradients of plume exposure. Detailed bathymetric mapping is required to identify the more distant paths and fate of the dense plume waters. Urea and ammonium should be measured in future studies; urea is added to fertilize the ponds, and ammonium is a common nitrogenous excretion of shrimp. Potentially harmful dinoflagellate species (e.g. Donophysis miles, Gonyaulax spinifera) have previously been observed in Al-Lith coastal waters (Kürten et al. 2015). Thus urea enrichment may contribute to harmful algal blooms because it is preferred over nitrate and nitrite by some dinoflagellates species (Glibert et al. 2005) and can increase domoic acid production in the toxic diatoms Pseudo-nitzschia spp. (Armstrong Howard et al. 2007). Moreover, the plume may hold chemosensory cues (e.g. dimethyl sulfide, DMS) that can affect the aggregation of whale sharks (Martin 2007, Hay 2009, Savoca \& Nevitt 2014, Dove 2015). In an aquarium study, whale sharks displayed foraging behavior when encountering DMS and homogenized krill solution (Dove 2015). Further chemical analyses could reveal influences from the plume on whale shark behavior.

Aquaculture is increasingly relied upon to supplement the global food supply, and this facility is a financial asset for the Kingdom of Saudi Arabia. The environmental impacts must be further assessed to protect the surrounding marine ecosystem and water quality that supports local fishermen and ecotourism. Better understanding of these impacts will enable operators and regulatory agencies to assess the carrying capacity of coastal seas for large aquaculture operations.

Acknowledgements. We thank Mohd Ikram Ansari and KAUST Analytical CoreLab for the nutrient analysis. We are grateful for the field and logistical support from the RV 'Thuwal' captain and crew, Francis Mallon, Lloyd Smith, Ioannis Georgakakis, Ajay Sancheti, Brian Hession, Gazi Aljehdali, KAUST Coastal and Marine Resources Core Laboratory, Jesse Cochran, Isabelle Schulz, Fernando Cagua, Amr Gusti, Pedro De La Torre, Joseph DiBattista, Moustapha Harb, Ahmed Shibl, Maha Khalil, and Dream Divers in Al-Lith. The research reported in this publication was supported by funding from KAUST.

\section{LITERATURE CITED}

Ackefors H, Enell M (1994) The release of nutrients and organic matter from aquaculture systems in Nordic countries. J Appl Ichthyol 10:225-241
Ansari MI, Harb M, Jones B, Hong PY (2015) Molecularbased approaches to characterize coastal microbial community and their potential relation to the trophic state of Red Sea. Sci Rep 5:9001

Arar EJ, Collins GB (1997) In vitro determination of chlorophyll $a$ and pheophytin $a$ in marine and freshwater algae by fluorescence. National Exposure Research Laboratory, Office of Research and Development, U.S. Environmental Protection Agency, Washington, DC

Armstrong Howard MD, Cochlan WP, Ladizinsky N, Kudela RM (2007) Nitrogenous preference of toxigenic Pseudonitzschia australis (Bacillariophyceae) from field and laboratory experiments. Harmful Algae 6:206-217

*Berrendero E, Perona E, Mateo P (2011) Phenotypic variability and phylogenetic relationships of the genera Tolypothrix and Calothrix (Nostocales, Cyanobacteria) from running water. Int J Syst Evol Microbiol 61:3039-3051

*Berumen ML, Braun CD, Cochran JEM, Skomal GB, Thorrold SR (2014) Movement patterns of juvenile whale sharks tagged at an aggregation site in the Red Sea. PLOS ONE 9:e103536

*Bowman JP, Nichols CM, Gibson JAE (2003) Algoriphagus ratkowskyi gen. nov., sp. nov., Brumimicrobium glaciale gen. nov., sp. nov., Cryomorpha ignava gen. nov., sp. nov. and Crocinitomix catalasitica gen. nov., sp. nov., novel flavobacteria isolated from various polar habitats. Int J Syst Evol Microbiol 53:1343-1355

* Braun CD, Skomal GB, Thorrold SR, Berumen ML (2014) Diving behavior of the reef manta ray links coral reefs with adjacent deep pelagic habitats. PLOS ONE 9:e88170

*Brzezinski M (1985) The Si:C:N ratio of marine diatoms: interspecific variability and the effect of some environmental variables. J Phycol 21:347-357

* Burford MA, Costanzo SD, Dennison WC, Jackson CJ and others (2003) A synthesis of dominant ecological processes in intensive shrimp ponds and adjacent coastal environments in NE Australia. Mar Pollut Bull 46:1456-1469

Carpenter KE, Abrar M, Aeby G, Aronson RB and others (2008) One-third of reef-building corals face elevated extinction risk from climate change and local impacts. Science 321:560-563

Cho Y, Chung H, Jang GI, Choi DH, Noh JH, Cho BC (2013) Gracilimonas rosea sp. nov., isolated from tropical seawater, and emended description of the genus Gracilimonas. Int J Syst Evol Microbiol 63:4006-4011

Coles SL (1988) Limitations on reef coral development in the Arabian Gulf: temperature or algal competition? Proc 6th Int Coral Reef Symp 3:211-216

Coles SL (2003) Coral species diversity and environmental factors in the Arabian Gulf and the Gulf of Oman: a comparison to the Indo-Pacific region. Atoll Res Bull 507: $1-19$

Cullen JJ (1982) The deep chlorophyll maximum: comparing vertical profiles of chlorophyll a. Can J Fish Aquat Sci 39:791-803

* D'Elia CF, Sanders JG, Boynton WR (1986) Nutrient enrichment studies in a coastal plain estuary: phytoplankton growth in large-scale, continuous cultures. Can J Fish Aquat Sci 43:397-406

*Dove ADM (2015) Foraging and ingestive behaviors of whale sharks, Rhincodon typus, in response to chemical stimulus cues. Biol Bull (Woods Hole) 228:65-74

*Dugdale RC, Wilkerson FP (1998) Silicate regulation of new production in the equatorial Pacific upwelling. Nature 
391:270-273

Furby KA, Apprill A, Cervino JM, Ossolinski JE, Hughen KA (2014) Incidence of lesions on Fungiidae corals in the eastern Red Sea is related to water temperature and coastal pollution. Mar Environ Res 98:29-38

Gladstone W, Tawfiq N, Nasr D, Andersen I and others (1999) Sustainable use of renewable resources and conservation in the Red Sea and Gulf of Aden: issues, needs and strategic actions. Ocean Coast Manag 42:671-697

Glibert PM, Trice TM, Michael B, Lane L (2005) Urea in the tributaries of the Chesapeake and coastal bays of Maryland. Water Air Soil Pollut 160:229-243

Grasshoff K, Kremling K, Ehrhardt M (eds) (2009) Methods of seawater analysis, 3rd edn. Wiley-VCH, Weinheim

* Hahn MW (2009) Description of seven candidate species affiliated with the phylum Actinobacteria, representing planktonic freshwater bacteria. Int J Syst Evol Microbiol 59:112-117

Hahn MW, Schmidt J, Taipale SJ, Doolittle WF, Koll U (2014) Rhodoluna lacicola gen. nov., sp. nov., a planktonic freshwater bacterium with stream-lined genome. Int J Syst Evol Microbiol 64:3254-3263

Harb M, Xiong Y, Guest J, Amy G, Hong P (2015) Differences in microbial communities and performance between suspended and attached growth anaerobic membrane bioreactors treating synthetic municipal wastewater. Environ Sci Water Res Technol 1:800-813

Hay ME (2009) Marine chemical ecology: chemical signals and cues structure marine populations, communities, and ecosystems. Annu Rev Mar Sci 1:193-212

Islam MS, Tanaka M (2004) Impacts of pollution on coastal and marine ecosystems including coastal and marine fisheries and approach for management: a review and synthesis. Mar Pollut Bull 48:624-649

Ivanova EP, Flavier S, Christen R (2004) Phylogenetic relationships among marine Alteromonas-like proteobacteria: emended description of the family Alteromonadaceae and proposal of Pseudoalteromonadaceae fam. nov., Colwelliaceae fam. nov., Shewanellaceae fam. Int J Syst Evol Microbiol 54:1773-1788

Ivanova EP, Zhukova NV, Lysenko AM, Gorshkova NM, Sergeev AF, Mikhailov VV, Bowman JP (2005) Loktanella agnita sp. nov. and Loktanella rosea sp. nov., from the north-west Pacific Ocean. Int J Syst Evol Microbiol 55: 2203-2207

Jackson C, Preston N, Thompson PJ (2004) Intake and discharge nutrient loads at three intensive shrimp farms. Aquacult Res 35:1053-1061

Jang GI, Cho Y, Cho BC (2013) Pontimonas salivibrio gen. nov., sp. nov., a new member of the family Microbacteriaceae isolated from a seawater reservoir of a solar saltern. Int J Syst Evol Microbiol 63:2124-2131

Khan ST, Fukunaga Y, Nakagawa Y, Harayama S (2007) Emended descriptions of the genus Lewinella and of Lewinella cohaerens, Lewinella nigricans and Lewinella persica, and description of Lewinella lutea sp. nov. and Lewinella marina sp. nov. Int J Syst Evol Microbiol 57: 2946-2951

Kheireddine M, Ouhssain M, Claustre H, Uitz J, Gentili B, Jones BH (2017) Assessing pigment-based phytoplankton community distributions in the Red Sea. Front Mar Sci 4:132

Knoema (2016) Population and Housing Census of Saudi Arabia, 2007-2025. Knoema, McLean, VA. Available at
https://knoema.com/SAPHC2010/population-andhousing-census-of-saudi-arabia-2007-2025?location= 1001140-hubuna

Kürten B, Khomayis HS, Devassy R, Audritz S and others (2015) Ecohydrographic constraints on biodiversity and distribution of phytoplankton and zooplankton in coral reefs of the Red Sea, Saudi Arabia. Mar Ecol 36: 1195-1214

Martin RA (2007) A review of behavioural ecology of whale sharks (Rhincodon typus). Fish Res 84:10-16

*Páez-Osuna F (2001) The environmental impact of shrimp aquaculture: causes, effects, and mitigating alternatives. Environ Manag 28:131-140

* Pastorok RA, Bilyard GR (1985) Effects of sewage pollution on coral-reef communities. Mar Ecol Prog Ser 21: 175-189

Petrenko AA, Jones BH, Dickey TD, Lehaitre M, Moore C (1997) Effects of a sewage plume on the biology, optical characteristics, and particle size distributions of coastal waters. J Geophys Res 102:25061-25071

* Petrenko AA, Jones BH, Dickey TD (1998) Shape and initial dilution of Sand Island, Hawaii sewage plume. J Hydraul Eng 124:565-571

* Richardson TL, Cullen JJ (1995) Changes in buoyancy and chemical composition during growth of a coastal marine diatom: ecological and biogeochemical consequences. Mar Ecol Prog Ser 128:77-90

Roberts DA, Johnston EL, Knott NA (2010) Impacts of desalination plant discharges on the marine environment: a critical review of published studies. Water Res 44:5117-5128

Rogowski P, Terrill E, Otero M, Hazard L, Middleton B (2012) Mapping ocean outfall plumes and their mixing using autonomous underwater vehicles. J Geophys Res 117:C07016

Kavoca MS, Nevitt GA (2014) Evidence that dimethyl sulfide facilitates a tritrophic mutualism between marine primary producers and top predators. Proc Natl Acad Sci USA 111:4157-4161

K Sawall Y, Kürten B, Hoang BX, Sommer U and others (2014) Coral communities, in contrast to fish communities, maintain a high assembly similarity along the large latitudinal gradient along the Saudi Red Sea Coast. J Ecosyst Ecography S4:003

Sheppard CRC (1988) Similar trends, different causes: responses of corals to stressed environments in Arabian Seas. Proc 6th Int Coral Reef Symp 3:297-302

* Shireman JV, Cichra CE (1994) Evaluation of aquaculture effluents. Aquaculture 123:55-68

Simon M, Grossart HP, Schweitzer B, Ploug H (2002) Microbial ecology of organic aggregates in aquatic ecosystems. Aquat Microb Ecol 28:175-211

Slade WH, Boss E (2015) Spectral attenuation and backscattering as indicators of average particle size. Appl Opt 54: 7264-7277

* Snider DM, Andrews MJ (1994) Rayleigh-Taylor and shear driven mixing with an unstable thermal stratification. Phys Fluids 6:3324

* Spinrad RW (1986) A calibration diagram of specific beam attenuation. J Geophys Res Oceans 91:7761-7764

Takai K, Moser DP, Onstott TC, Spoelstra N, Pfiffner SM, Dohnalkova A, Fredrickson JK (2001) Alkaliphilus transvaalensis gen. nov., sp. nov., an extremely alkaliphilic bacterium isolated from a deep South African gold mine. Int J Syst Evol Microbiol 51:1245-1256 
Turner RE, Qureshi N, Rabalais NN, Dortch Q, Justic D, Shaw R, Cope J (1998) Fluctuating silicate:nitrate ratios and coastal plankton food webs. Proc Natl Acad Sci USA 95:13048-13051

Van Trappen S, Tan TL, Yang J, Mergaert J, Swings J (2004) Alteromonas stellipolaris sp. nov., a novel, budding, prosthecate bacterium from Antarctic seas, and emended description of the genus Alteromonas. Int $\mathrm{J}$ Syst Evol Microbiol 54:1157-1163

Weon HY, Kim BY, Lee CM, Hong SB, Jeon YA, Koo BS, Kwon SW (2009) Solitalea koreensis gen. nov., sp. nov. and the reclassification of [Flexibacter] canadensis as Solitalea canadensis comb. nov. Int J Syst Evol Microbiol
59:1969-1975

* Winters H, Isquith IR, Bakish R (1979) Influence of desalination effluents on marine ecosystems. Desalination 30: 403-410

Ziemann DA, Walsh WA, Saphore EG, Fulton-Bennett K (1992) A survey of water quality characteristics of effluent from Hawaiian aquaculture facilities. J World Aquacult Soc 23:180-191

Zubkov MV, Fuchs BM, Tarran GA, Burkill PH, Amann R (2003) High rate of uptake of organic nitrogen compounds by Prochlorococcus cyanobacteria as a key to their dominance in oligotrophic oceanic waters. Appl Environ Microbiol 69:1299-1305 


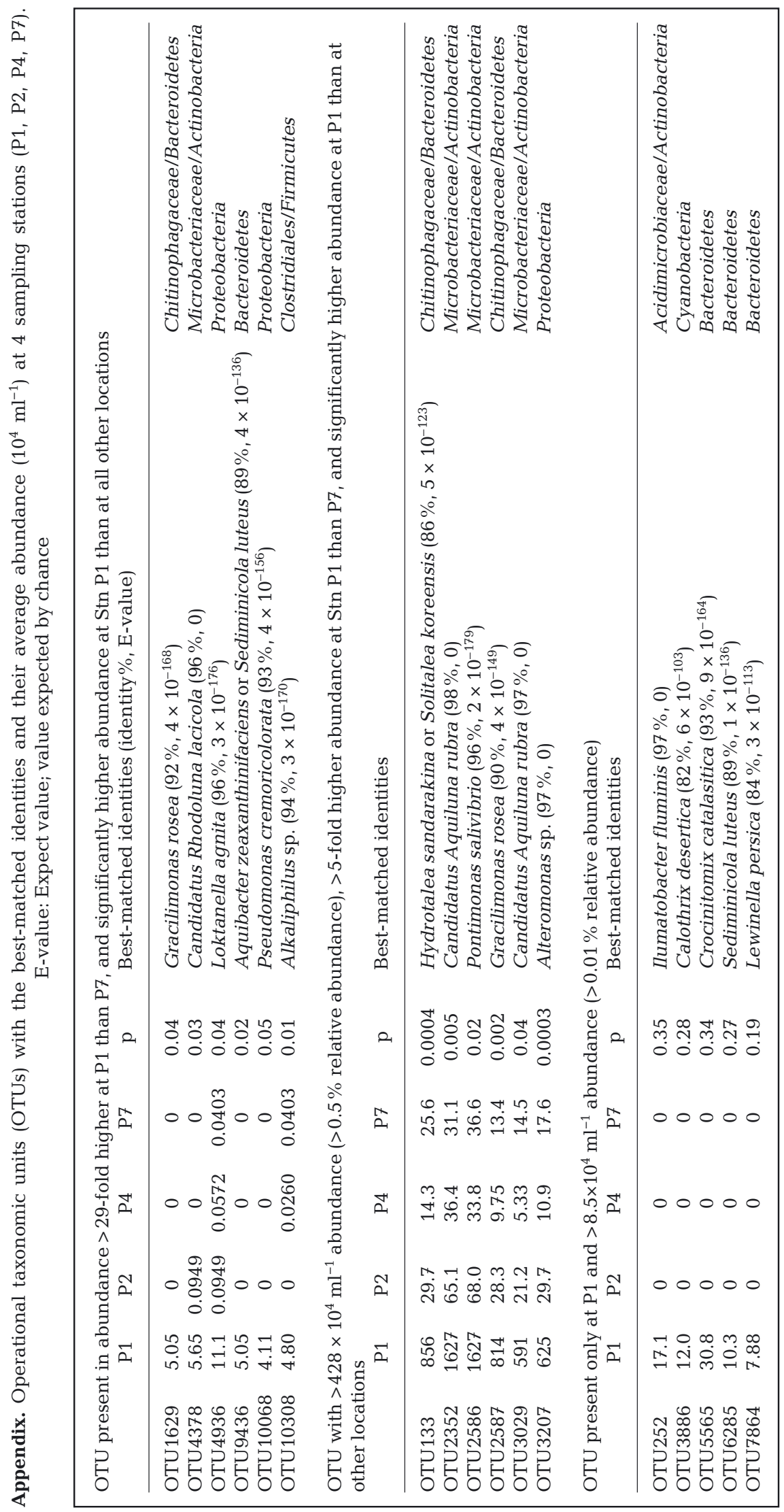

